Available online at GSC Online Press Directory

GSC Biological and Pharmaceutical Sciences

e-ISSN: 2581-3250, CODEN (USA): GBPSC2

Journal homepage: https://www.gsconlinepress.com/journals/gscbps

(RESEARCH ARTICLE)

\title{
Haematology and serum biochemistry of broiler strains (Cobbs and Arbor-acre) fed ginger (Zingiber officinale)
}

Iyaode Iyekeji Ifelayo *, Ibrahim Hajarah Onize, Uwade Faith and Shittu Mustapha Wodi

Department of Animal Production, Kogi State University, Anyigba, Nigeria.

Publication history: Received on 20 May 2020; revised on 26 May 2020; accepted on 27 May 2020

Article DOI: https://doi.org/10.30574/gscbps.2020.11.2.0145

\begin{abstract}
A 56-day trial was conducted to evaluate the effect of feeding ginger (Zingiber officinale) on the hematology and serum biochemistry of two strains (Cobbs and Arbor-acre) of broiler chickens. A total of one hundred and forty-four (144) day old chicks were randomly allocated into three dietary treatments groups $(\mathrm{T} 1=$ Basal diet $+0 \%$ Ginger inclusion, $\mathrm{T} 2=$ basal diet $+0.5 \%$ Ginger inclusion, T3 = Basal diet $+1.0 \%$ Ginger inclusion level) which were replicated three times within a Completely Randomized Design. The result showed that strains had significant influence $(\mathrm{p}<0.05)$ on the hematological indices of the chicks except for MCV, MCHC, lymphocyte. Cobbs showed better Pack Cell Volume and MCHC While Arbor acre showed better Haemoglobin, Red Blood Cell, WBC, Mean corpuscular haemoglobin and neutrophils. For the serum biochemistry, significant variation $(\mathrm{p}<0.05)$ due to ginger inclusion was observed. Total protein and albumin increased with increase in ginger inclusion level while cholesterol, TG, LDL, creatinine, AST and ALT decreased with increase in ginger inclusion. Albumin and aspartate transaminase were significantly affected $(\mathrm{p}<0.05)$ by strain effect, with Cobbs showing higher value for albumin and lower value for AST. Birds fed with Ginger inclusion level of $1 \%$ showed better health status as measured by hematology and serum biochemistry with the Cobbs strain showing better performance than the Arbor-acre strain.
\end{abstract}

Keywords: Haematology; Serum biochemistry; Broiler strains; Ginger

\section{Introduction}

According to [1], broiler chickens are fast growing birds and are described as good converters of feed. They are marketed from eight to twelve weeks. However, the production of broiler chickens as meat bird cannot be effective in the absence of adequate feed and feed ingredients in right proportion.

Spices and herbs are very common to be useful feed additives in broiler diets [2]. The supplement of spices and herbs could have many benefits to broiler health and such as having anti-oxidative potential [3], antimicrobial activity [4] enhancing digestion by stimulating endogenous enzymes. Ginger (Zingiber officinale) has been reported as one of the commonly used herbs in feed, it is reported for its various medicinal properties such as analgesic, antiemetic, antiulcer, antipyretic and cardio-depressant among others [5].

Blood testing is commonly used to help diagnose illness in broilers in order to determine the state of the broilers health. Hematology is the scientific study of the nature, function and disease of blood which can provide important information for diagnosis and disease in animals while Serum biochemistry refers to the chemical analysis of blood serum. These parameters have been observed as good indicators of the physiological status of animal and their changes are important in assessing the response of such animals to various physiological situations [6].

\footnotetext{
* Corresponding author: Iyaode Iyekeji Ifelayo
} 


\subsection{Justification of the Study}

Hematology and serum parameters have been observed to be good indicators of the physiological status of animal and changes in them are important in assessing the response of animal to various physiological and nutritional situations. It is therefore, important to evaluate blood parameters of birds fed with graded levels of ginger, such information would be very beneficial in accessing the health status of such birds.

\subsection{Objective of the Study}

The objective of the study is to assess the health status of different strains of broiler chickens fed graded levels of Ginger through their haematological indices and serum biochemistry.

\section{Materials and methods}

\subsection{Experimental Site}

The study was carried out in the Poultry Unit of the Teaching and Research Farm of the Department of Animal Production, Kogi State University, Anyigba in Dekina Local Government Area of Kogi State. Anyigba is located on Latitude $7030^{\prime} \mathrm{N}$ of the equator and Longitude 7o09'E of the Greenwich meridian and with an average altitude of 420 metres above the sea level. The study area falls within tropical wet and dry climate region of the Guinea savanna, with average annual rainfall of $1600 \mathrm{~mm}$ and daily temperature range of about $250 \mathrm{C}-35 \mathrm{OC}$ [ 7].

\subsection{Collection, Processing and Preparation of the Experimental Diet}

Fresh ginger (Zingiber officinale) was purchased from Suleja market in Niger State. They were washed, peeled, chopped into smaller pieces, dried and ground into powder. The obtained powder was packed in a polyethylene bag and preserved in the feed storage room until used for feed formulation. The experiment lasted for eight (8) weeks. Ginger powder was incorporated into the experimental diet manually in appropriate doses. The experimental basal diet was formulated with a crude protein of $23 \%$ at the starter phase $(0-4$ weeks) and a crude protein of $21 \%$ at the finisher phase (5-8 weeks).

\subsection{Experimental Treatment}

A total of one hundred and forty-four (144) day old chick of mixed sexes comprising of two different strains (Arbor acre and Cobbs) were randomly assigned to three different experimental treatment groups. Treatment one (T1 = basal diet only); Treatment two (T2 = basal diet $+0.5 \%$ ginger $)$; Treatment three $(\mathrm{T} 3=$ basal diet $+1.0 \%$ ginger $)$. Each of the treatment group per strain was replicated three (3) times with eight (8) chicks per replicate making a total of eighteen (18) compartments for the two strains.

\subsection{Management of birds}

All the necessary management practices for broiler chickens like brooding, vaccinations, feeding, sanitation, record keeping, veterinary services were strictly adhered to.

\subsection{Data collection/ method of collection}

Data collected for haematological parameters were [packed cell volume (PCV), red blood cell count (RBC), white blood cell (WBC), haemoglobin, mean corpuscular haemoglobin (MCH), Mean corpuscular concentration (MCHC) and platelets] while data collected for serum biochemistry were [Albumin (g/dl), Total protein (g/dl), Glucose (g/dl), AST (g/dl), ALT (g/dl), Triglyceride (g/dl), cholesterol (g/dl), HDL (g/dl), LDL (g/dl), Globulin (g/dl)].

\subsection{Statistical Analysis}

Data collected over the course of the experiment was subjected to the statistical analysis of variance (ANOVA) as appropriate for a $2 \times 3$ factorial arrangement implemented within a completely randomized design (CRD) using Statistical Package for Social Sciences (SPSS version 20). Significant means were separated using LSD at 5\% level of significance. 


\section{Results and discussion}

Table 1 Strain Effect on the Hematological profile of broilers fed ginger

\begin{tabular}{lllll}
\hline Parameter & Arbor acre & Cobbs & SEM & LOS \\
\hline PCV (\%) & $31.50^{\mathrm{b}}$ & $32.83^{\mathrm{a}}$ & 0.25 & $*$ \\
$\mathrm{Hb}(\mathrm{g} / \mathrm{d})$ & $10.38^{\mathrm{a}}$ & $10.12^{\mathrm{b}}$ & 0.14 & $*$ \\
RBC $\left(\mathrm{x} 10^{12} / \mathrm{L}\right)$ & $3.08^{\mathrm{a}}$ & $2.98^{\mathrm{b}}$ & 0.09 & $*$ \\
WBC $\left(\mathrm{x} 10^{9} / \mathrm{L}\right)$ & $224.96^{\mathrm{a}}$ & $217.90^{\mathrm{b}}$ & 3.82 & $*$ \\
MCV (fl) & 120.02 & 121.47 & 1.79 & NS \\
MCH (pg) & $36.21^{\mathrm{a}}$ & $34.94^{\mathrm{b}}$ & 0.48 & $*$ \\
MCHC (g/dL) & $33.21^{\mathrm{b}}$ & $33.42^{\mathrm{a}}$ & 0.26 & NS \\
Neutrophil ( x10 $/ \mathrm{L})$ & $3.17^{\mathrm{a}}$ & $2.83^{\mathrm{b}}$ & 0.15 & $*$ \\
Lymphocytes $\left(x 10^{9} / \mathrm{L}\right)$ & $96.06^{\mathrm{a}}$ & $95.44^{\mathrm{b}}$ & 0.74 & NS \\
\hline LOS = Level of significance, SEM = Standard error of mean, abc = means on the same row with different
\end{tabular}

Superscript is significantly different $(\mathrm{p}<0.05), \mathrm{PCV}=$ Packed cell volume, $\mathrm{Hb}=$ Hemoglobin, $\mathrm{WBC}=\mathrm{White} \mathrm{Blood}$ Cell, $\mathrm{RBC}=\mathrm{Red} \mathrm{Blood}$ Cell, $\mathrm{MCV}=$ Mean Corpucular Volume, $\mathrm{MCH}=$ Mean Corpuscular Hemoglobin, MCHC = Mean Corpuscular Haemoglobin Concentration

Result obtained in table 1 showed that strain had significant influence $(\mathrm{p}<0.05)$ on the hematological indices of the birds except for MCV, MCHC and lymphocytes. Arbor-acre showed significantly higher values than cobbs in most of the parameters examined except for PCV and MCHC. These values for PCV though significantly different $(\mathrm{p}<0.05)$ yet corresponds with normal ranges of 35-55\% reported by [8] for healthy birds and $24.90-45.20 \%$ reported by [9]. These values for HB though significantly different $(\mathrm{p}<0.05)$ yet corresponds with normal ranges of $8.93-10.45$ reported by [10] as normal range for broiler. [10] reported values range of 26.50 to $32.50,8.93$ to $10.45,3.08$ to 3.53 , and 3.53 to 3.80 for PCV, Hb, WBC and RBC respectively as normal range for broiler. Hematological factors are used to describe the health status of animal and stress due to environment, nutrition and pathological factors. This is greatly influenced by the innate ability (Genotypic ability of the animal to thrive under such condition). The various ability to survive and thrive is innate in the breed and strain of the animal [11].

Table 2 Treatment Effect on the Hematology of Broiler Chicken fed Ginger

\begin{tabular}{llllll}
\hline Parameter & T1 (0\%) & T2 (0.5\%) & T3 (1\%) & SEM & LOS \\
\hline PCV (\%) & $30.83^{\mathrm{c}}$ & $31.83^{\mathrm{b}}$ & $32.33^{\mathrm{a}}$ & 0.31 & $*$ \\
Hb $(\mathrm{g} / \mathrm{d})$ & $9.68^{\mathrm{b}}$ & $10.52^{\mathrm{a}}$ & $10.56^{\mathrm{a}}$ & 0.24 & $*$ \\
RBC $\left(\times 10^{12} / \mathrm{L}\right)$ & $2.97^{\mathrm{b}}$ & $2.94^{\mathrm{b}}$ & $3.18^{\mathrm{a}}$ & 0.12 & $*$ \\
WBC $\left(\times 10^{9} / \mathrm{L}\right)$ & $211.39^{\mathrm{c}}$ & $222.15^{\mathrm{b}}$ & $230.75^{\mathrm{a}}$ & 4.67 & $*$ \\
MCV (fl) & $118.19^{\mathrm{b}}$ & $121.78^{\mathrm{a}}$ & $122.30^{\mathrm{a}}$ & 2.19 & $*$ \\
MCH (pg) & $35.25^{\mathrm{b}}$ & $35.28^{\mathrm{b}}$ & $36.18^{\mathrm{a}}$ & 0.59 & $*$ \\
MCHC (g/dL) & 33.16 & 33.38 & 33.39 & 0.41 & NS \\
Neutrophil (x10 $/ \mathrm{L})$ & $2.92^{\mathrm{b}}$ & $2.92^{\mathrm{b}}$ & $3.17^{\mathrm{a}}$ & 0.19 & $*$ \\
Lymphocytes $\left(\mathrm{x} 10^{9} / \mathrm{L}\right)$ & $94.50^{\mathrm{c}}$ & $95.92^{\mathrm{ab}}$ & $96.83^{\mathrm{a}}$ & 0.91 & $*$ \\
\hline
\end{tabular}

LOS = Level of significance, SEM = Standard error of mean, abc = means on the same row with different superscript are significantly different $(\mathrm{p}<0.05), \mathrm{PCV}=$ Packed cell volume, $\mathrm{Hb}=$ Hemoglobin, $\mathrm{WBC}=$ White Blood Cell, $\mathrm{RBC}=$ Red Blood Cell, $\mathrm{MCV}=\mathrm{Mean}$ Corpuscular Volume, $\mathrm{MCH}=$ Mean Corpuscular Hemoglobin, $\mathrm{MCHC}=$ Mean Corpuscular Haemoglobin Concentration

Result obtained in table 2 showed that Pack Cell Volume showed significant difference $(\mathrm{p}<0.05)$ across treatment with birds in T3 (ginger 1\%) having the highest value (33.33). Though significant difference $(\mathrm{p}<0.05)$ among treatment groups exist, yet the range is within the PCV range of (28.75 - 49.33\%), (26.0 - 45.20\%) and (32-35\%) is within the normal values reported by [12]. PCV when too high is an indicator of toxic factors which could have adverse effect on the formation of blood. There was significant difference $(p<0.05)$ for observed for Haemoglobin showing T3 $(10.56$ 
$\mathrm{g} / \mathrm{dl}$ ) to be significantly higher than T1 but it was not significantly different from T2. Range of haemoglobin observed was $9.43 \mathrm{~g} / \mathrm{dl}-10.50 \mathrm{~g} / \mathrm{dl}$. White blood cell value though significantly difference $(\mathrm{p}<0.05)$ among treatment means, did not follow a particular order. T3 had the highest value of 230.75, while T2 (211.15) had the least value. The range of WBC $(211.39$ - 230.75). This are within range for normal birds [13]. Values for Red Blood Cell showed significant difference $(\mathrm{p}<0.05)$ across treatment with the highest observed in T3 which was significantly different from T2 and T1. Range values for RBC was 2.97-3.18 x 106. This shows that birds fed ginger $1 \%$ had more red blood cell; which could imply that ginger have some innate quality to stimulate the production of red blood cells through vitamin synthesis. With PCV, Hb and RBC been within normal range, could be an indicator of the bride marrow of the birds functioning normally thereby stimulating RBC formation. Mean cell volume (MCV) also showed significant difference at $(p<0.05)$. Range of value were $118.19 \mathrm{fl}-122.30 \mathrm{fl}$. Mean corpuscular heamoglobin MCH also showed significance difference $\mathrm{p}<0.05$ with value of T1 having $36.18 \mathrm{pg}$ as the least while T3 with $36.18 \mathrm{pg}$ as the highest. Mean cell haemoglobin concentration showed significant variation at $\mathrm{p}<0.05$. Highest level recorded was at $\mathrm{T} 3(1 \%$ ginger $) 36.18 \mathrm{~g} / \mathrm{dl}$ which varied with T2 (ginger $0.5 \%) 35.28 \mathrm{pg} / \mathrm{dl}$ and T1 $33.16 \mathrm{~g} / \mathrm{dl}$ (control). Range of values $(35.25 \mathrm{~g} / \mathrm{dl}$ and $36.18 \mathrm{~g} / \mathrm{d} 1$ ) is similar to the normal range reported by [9]. Result on the differential indicates that the inclusion of ginger at pharmaceutical levels did not alter the energy-protein balance in the diet. Result for Hematological proteins (neutrophil and lymphocytes) showed significant difference $(\mathrm{p}<0.05)$ with T3 having significantly higher values $(\mathrm{p}<0.05)(3.17$, $96.83)$ for neutrophil and lymphocytes respectively as compared to $\mathrm{T} 2$ and $\mathrm{Tl}(2.92,95.92),(2.92,94.50)$ respectively.

Table 3 Strain Effects on serum biochemistry of Broilers fed Ginger

\begin{tabular}{llll}
\hline Parameter & Arbor acre & Cobbs & LOS \\
\hline Total Protein $(\mathrm{g} / \mathrm{dl})$ & $4.17 \pm 0.05$ & $4.27 \pm 0.05$ & NS \\
Albumin $(\mathrm{g} / \mathrm{dl})$ & $2.09^{\mathrm{b}} \pm 0.03$ & $2.19^{\mathrm{a}} \pm 0.03$ & $*$ \\
Globulin $(\mathrm{g} / \mathrm{dl})$ & $2.08 \pm 0.05$ & $2.08 \pm 0.05$ & $\mathrm{NS}$ \\
Cholesterol $(\mathrm{g} / \mathrm{dl})$ & $199.56 \pm 3.66$ & $193.89 \pm 3.66$ & NS \\
Triglyceride $(\mathrm{g} / \mathrm{dl})$ & $131.97 \pm 8.57$ & $118.86 \pm 8.57$ & NS \\
LDL (g/dl) & $111.34 \pm 2.55$ & $106.46 \pm 2.55$ & NS \\
HDL (g/dl) & $54.97 \pm 0.96$ & $53.90 \pm 0.96$ & NS \\
Creatinine $(\mathrm{g} / \mathrm{dl})$ & $0.79 \pm 0.03$ & $0.81 \pm 0.03$ & NS \\
AST (g/dl) & $199.61^{\mathrm{a} \pm 2.32}$ & $193.03^{\mathrm{b}} \pm 2.32$ & $*$ \\
ALT (g/dl) & $6.64 \pm 0.29$ & $6.96 \pm 0.29$ & NS \\
\hline
\end{tabular}

$a b c=$ means with different superscripts along the same row show significant difference at $\mathrm{p}<0.05, \mathrm{LDL}=$ low density lipoprotein, $\mathrm{HDL}=\mathrm{high}$ density lipoprotein, $\mathrm{AST}=$ alanine transfarase, $\mathrm{AST}=$ aspartate transferase

Result obtained in Table 3 showed that strain had significant influence $(\mathrm{p}<0.05)$ on albumin and aspartate aminotransferase (AST) where significant higher value $(p<0.05)$ for albumin $(2.19)$ were recorded for Cobbs strain while AST was higher in the arbor acre strain. The strain influence on the serum biochemical properties showed a significantly $(\mathrm{P}<0.05)$ higher Globulin values in Cobbs strain, thus suggesting a better utilization of protein in the diet offered irrespective of the inclusion level. This further implies higher levels of digestion, assimilation and utilization of the feed offered by the Cobbs strain. The main functions of albumin are the transport of several molecules and the maintenance of blood osmotic pressure [14] thus implying a healthier condition for the Cobbs strain. The hepatic toxicity (AST) to ginger rhizome offered at different level of inclusion was significantly higher for arbor acre strain. This indicates more susceptibility to toxicity for the arbor acre. Although this is not a

specific test for providing information about hepatic function, but when AST activity is greater than $800 \mathrm{IU} / \mathrm{L}$, it is indicative of a severe hepatic disorder [14]. In most species including birds, plasma ALT activity, also increases in such situations but has not get convenient advantage over AST as a test for hepatocellular disease [15].

Both strain had general normal levels of serum AST. There is enough evidence that broilers show inflammatory changes in the liver through their life [16]. In this study, the increased AST in the arbor acre group indicates that their slow growth rate could indicate liver lesions. The increased level of AST might not be a signal for worries as the thresh-hold is not exceeded. 
Iyaode et al. / GSC Biological and Pharmaceutical Sciences, 2020, 11(02), 320-326

Table 4 Effects of treatment on serum biochemistry of Broilers fed Ginger

\begin{tabular}{lllll}
\hline Parameter & T1(0\%) & T2(0.5\%) & T3(1\%) & LOS \\
\hline Total Protein (g/dl) & $4.18^{\mathrm{b}} \pm 0.06$ & $4.23^{\mathrm{a}} \pm 0.06$ & $4.23^{\mathrm{a}} \pm 0.06$ & $*$ \\
Albumin (g/dl) & $2.10^{\mathrm{b}} \pm 0.036$ & $2.13^{\mathrm{b}} \pm 0.036$ & $2.15^{\mathrm{a}} \pm 0.036$ & $*$ \\
Globulin (g/dl) & $2.08^{ \pm} \pm 0.07$ & $2.10 \pm 0.07$ & $2.08^{ \pm} \pm 0.07$ & NS \\
Cholesterol (g/dl) & $215.27^{\mathrm{a}} \pm 4.48$ & $198.72^{\mathrm{b}} \pm 4.48$ & $176.15^{\mathrm{c}} \pm 4.5$ & $*$ \\
Triglyceride (g/dl) & $132.22^{\mathrm{a}} \pm 10.497$ & $118.86^{\mathrm{b}} \pm 10.50$ & $110.07^{\mathrm{b}} \pm 10.50$ & $*$ \\
LDL (g/dl) & $124.92^{\mathrm{a}} \pm 3.12$ & $111.87^{\mathrm{b}} \pm 3.12$ & $89.92^{\mathrm{c}} \pm 3.12$ & $*$ \\
HDL (g/dl) & $55.37^{\mathrm{a}} \pm 1.17$ & $54.12^{ \pm} \pm 1.17$ & $53.82^{ \pm} \pm 1.17$ & NS \\
Creatinine (g/dl) & $1.03^{\mathrm{a}} \pm 0.03$ & $0.79^{\mathrm{b}} \pm 0.030$ & $0.59^{\mathrm{c}} \pm 0.03$ & $*$ \\
AST (g/dl) & $213.61^{\mathrm{a}} \pm 13.21$ & $200.08^{\mathrm{b}} \pm 13.21$ & $175.27^{\mathrm{b}} \pm 13.21$ & $*$ \\
ALT (g/dl) & $7.69^{\mathrm{a}} \pm 0.35$ & $6.49^{\mathrm{b}} \pm 0.35$ & $6.22^{\mathrm{b}} \pm 0.35$ & $*$ \\
\hline
\end{tabular}

$\mathrm{abc}=$ means with different superscripts along the same row show significant difference at $\mathrm{p}<0.05$, LDL = low density lipoprotein $\mathrm{HDL}=$ high density lipoprotein, ALT alanine transfarase, AST = aspartate transferace, $\mathrm{t} 1=0 \%, \mathrm{t} 2=0.5 \%, \mathrm{t} 3=1 \%$ ginger inclusion respectively

Result obtained in Table 4 showed that inclusion level of ginger significantly increased $(\mathrm{p}<0.05)$ Total Protein $(\mathrm{TP})$ and Albumin while Cholesterol, Triglycerides, LDL, Creatinine, AST and ALT were significantly $(\mathrm{p}<0.05)$ reduced from control group $(0 \%)$ to $1 \%$ ginger inclusion group. Globulin and HDL were not significantly affected by the inclusion of ginger. Total protein significantly differed ( $\mathrm{p}>0.05$ ) across treatment. Highest value of ( $4.23 \mathrm{~g} / \mathrm{dl})$ was recorded for T3. Total protein increased with increase in the quantity of ginger included in the treatment. Values obtained in this experiment were in agreement with data recorded by [17] for normal range of TP for broilers. Variation in total could be attributed to an improved digestion capacity conferred by the ginger present in the feed thereby making more protein available to the birds. This implies superiority of the 1\% ginger inclusion diet in protein balance in comparison with the other treatment diets. Albumin also was significantly improved ( $p>0.05)$ by the ginger inclusion. T3 $(2.15$ $\mathrm{g} / \mathrm{dl}$ ) recorded the highest value. A range of $2.10 \mathrm{~g} / \mathrm{dl}$ to $2.15 \mathrm{~g} / \mathrm{dl}$ was recorded. Albumin is important to the birds because of its blood clotting ability and transporting of insoluble substances in the blood [18]. Value range obtained in this study was in the normal range as reported by [17].

No significantly different ( $\mathrm{p}<0.05$ ) was observed for globulin. Highest value was recorded for T3 (2.08 g/dl). Range of $2.08 \mathrm{~g} / \mathrm{dl}$ to $2.10 \mathrm{~g} / \mathrm{dl}$ was recorded for globulin. Globulin and albumin are very essential indications to blood protein. Value range obtained for total protein, albumin and globulin though significantly different $(p>0.05)$ yet values are within range reported by [9] for healthy chicks. This implies that chick's immunity was not compromised at all levels of inclusion; but were significantly improved with increase in inclusion level of ginger. The dietary treatments affected the serum biochemistry of broilers, especially birds receiving $1.00 \%$ ginger which significantly modified HDL and LDL concentrations. [19] further established that the supplementation with ginger powder significantly decreased the levels of triglycerides, total cholesterol, LDL and very-low density lipoprotein (VLDL). In general, normal levels of blood protein and glucose indicate adequate nutritional status and normal systemic protein function. Low HDL levels and high VLDL triglyceride usually result in metabolic syndrome [20]; was not observed with the inclusion of ginger rather a reverse with a modification reducing the low density lipoproteins, triglycerides and cholesterol level faster than the high density lipoprotein. This implies an improved health status of the birds across the respective treatment groups [20].

Reduced levels of creatinine in response to increasing quantity of the ginger rhizome inclusion indicated that the fed broiler utilization of the protein in the feed was significantly improved as no problem with the quality of the protein in the test feed ingredient was observed. These findings were in variance with the works of [21] who fed birds with high levels of Moringa product and reported poor results due to anti-nutrients.

The ALT levels in the treatment 3 group decreased more rapidly than the control group. The inclusion of ginger may reduce the tendency for a gross liver failure which may have resulted in lowering of ALT [22] as seen in the 1\% ginger inclusion group. The control group (T1) broilers without ginger inclusion had a slight increase in ALT levels which can be due to the metabolic demand for the liver resulting from high feed intake [23]. This is further confirmed by level of daily feed intake in the control group. 
The treatment groups had general normal levels of serum AST [9]. There is enough evidence that broilers show some levels of inflammatory changes in the liver through their life [16]. In this study, the higher level of AST in the control group indicates that the growth rate of the broiler or non-optimal utilization of the feed ingredient could be the cause for the general liver lesions. The increased level of AST might be lowered due to inclusion of the ginger root meal caused by reduced digestion and utilization capacity of the affected treatment group. Increase in AST/ALT ratio may cause chronic liver damage in fast growing broilers [24] and this might result to an occurrence of sudden death syndrome (SDS) as reported by [25]. As clearly shown in the present study, the effect of feed intake on the ginger root meal significantly reduced the AST and ALT levels thereby creating a healthier state for the birds.

\section{Conclusion}

Generally, the hematological indices and serum biochemistry of birds administered ginger at various level of inclusion were significantly $(\mathrm{p}<0.05)$ higher than those of the control implying better utilization of the experimental materials by the birds. Since all the birds used in this experiment showed adequate normal range of values in all parameter analyzed, it could be concluded that with respect to the administration of ginger, optimum hematological and serum performance is achieved at an inclusion level of $1 \%$ in the diets of broilers.

The Cobbs Strain showed better utilization of ginger than the Arbor acre strain.

\section{Compliance with ethical standards}

\section{Acknowledgments}

The authors wish to acknowledge the management of Kogi State University Anyigba for the provision of the facility at the Livestock Teaching and Research Farm, we also appreciate its Technical staff for their kind support.

\section{Disclosure of conflict of interest}

All authors declare no conflict of interest exist.

\section{Statement of ethical approval}

The research was conducted in accordance with the ethical standard of the institution.

\section{References}

[1] Olomu JM. (1995). Monogastric Animal Nutrition, Principles and Practices. Jachem publication Nigeria, $19-65$.

[2] Zhang GF, Yang ZB, Wang Y, Yang WR, Jiang SZ and GAI GS. (2009). Effects of ginger root (Zingiber officinale) processed to different particle sizes on growth performance, antioxidant status, and serum metabolites of broiler chickens. Poultry Science, 88, 2159-2166.

[3] Hui YH. (1996). Oleoresins and essential oils. Barley's industrial oil and fat products. New York, wileyinterscience publication, cap, 6, 145-153.

[4] Dorman HJD and Deans SG. (2000). Antimicrobial agents from plants: Antibacterial activity of plant volatile oils. J. Appl. Microbial, 88(2), 308-316.

[5] Jana U, Chattopadhyay RN and Shaw BP. (1999). Preliminary studies on anti-inflammatory activity of Zingiber officinale Rosc., Vitex negundo Linn and Tinosporacordifolia (willid) Miers in albino rats. Indian Journal of pharmacology, 31, 232-233.

[6] Khan TA and Zafar F. (2005). Haematological study in response to varying doses of estrogen in broiler chicken. International Journal of Poultry Science, 10, 748-751.

[7] Ifetimehin 00, Musa SD and Adeyemi JO. (2011). Managing land use transformation and land surface temperature changes in Anyigba town Kogi State. Nigerian Journal of Animal production, 23(1), 94-97.

[8] McDonald MG. (1996).Users documentation for the U.S.G.S modular finite-difference ground water flow model. U.S.G.S Open File Report, 96-485, 56.

[9] Mitruka HM and Rawnsley SK. (1997). Chemical, Biochemical and Haematological Reference Values in Normal Experimental Animals. Masson Publishing, New York, USA, 287. 
[10] Oguntoye MA, Bako J, Adam F, Daniel DK, Daniel B and Joseph E. (2018). Effect of maize and yam peel based diet supplemented with xylanase, Amylase and Protease Multi-Enzymes on serum biochemistry and haematological indices of starter broiler chickens. Nigerian journal for animal science, 20(4), 355-363.

[11] Arnold SJ. (1994). Multivariate inheritance and evolution: a review of concept. Quantitative genetic studies of behavioral evolution. (Edition Boake, C.R.B.), 17-48.

[12] Fayeye TR, Adeshiyan AB and Olugbani AA. (2005). Egg Trait, Hatchability and Early Growth Performance of the Fulani-Ecotype Chicken. Livestock Research for Rural Development, 456.

[13] Ahiwe EU, Emenalom 00, Etuk EB and Okehie UN. (2014). Performance of 'kaura' variety of sorghum (Sorghum bicolor) based diet supplemented with enzyme. Nigeria journal of animal science, 15(1), 75-82.

[14] Melillo A. (2013). Applications of serum protein electrophoresis in exotic pet medicine. Veterinary Clinics of North America Exotic Animal Practice, 16(1), 211-225.

[15] Umit P, Derya Y and Mustafa E. (2011). Serum biochemical profile of broiler chickens fed diets containing rosemary and rosemary volatile oil. J. Biol. Environ. Sci, 5(13), 23-30.

[16] Singh D and Gupta RS. (2011). "Hepatoprotective activity of methanol extract of Tecomellaundulata against alcohol and paracetamol induced hepatotoxicity in rats." Life Science Med Res, 26, 1-8.

[17] Meluzzi A, Primiceri G, Giordani R and Fabris G. (1992). Determination of blood constituents reference values in broilers. Poultry science, 71(2), 337-345.

[18] Fischbach FT and Dunning MB. (2009). Amanual of laboratory and diagnostic tests. Philadelphia: Lippincott Williams \& Wilkins.

[19] Alizadeh-Navaei R, Roozbeh F, Saravi M, Pouramir M, Jalali F and Moghadamnia A. (2008). An investigation of the effect of ginger on the lipid levels. A double blind controlled clinical trial. Saudi Medical Journal, 29(9), 12801284.

[20] Ademola SG, Farinu GO and Babatunde GM. (2009). Serum lipid, growth and haematological parameters of broilers fed garlic, ginger and their mixtures. World Journal of Agricultural Science, 5, 99-104.

[21] Aregheore EM. (2012). Intake and digestibility of Moringa oleifera leaf meal in broilers. Journal for animal science, 46, 23-38.

[22] Rahimlou M, Yari Z, Hekmatdoost A, Alavian SM and Keshavarz SA. (2016). Ginger supplementation in nanalchoholic fatty liver disease: A randomized, double-blind, placebo-controlled pilot study. Hepatitis monthly, 16(1), e34897.

[23] Schindhelm RK, Diamant M, Dekker JM, Tushuizen ME, Teerlink T and Heine RJ. (2006). Alanine aminotransferase as a marker of non-alcoholic fatty liver disease in relation to type 2 diabetes mellitus and cardiovascular disease. Diabates/ Metabolosm Research and Reviews, 22(6), 437-443.

[24] Dudley RE, Svoboda DJ and Klaassen CD. (1982). Acute exposure to cadmium causes severe liver injury in rats. Toxicology and Applied Pharmacology, 65(2), 302-313.

[25] Qujec D and Aliakbarpour HR. (2005). Serum Activities of Enzymes in Broiler Chickens that Died from Sudden Death Syndrome. Pakistan Journal of Biological Sciences, 8(8), 1078 - 1080.

\section{How to cite this article}

Iyaode II, Ibrahim HO, Uwade F and Shittu MW. (2020). Haematology and serum biochemistry of broiler strains (Cobbs and Arbor-acre) fed ginger (Zingiber officinale). GSC Biological and Pharmaceutical Sciences, 11(2), 320-326. 